Review

\title{
Advances in the Molecular Cytogenetics of Bananas, Family Musaceae
}

\author{
Denisa Šimoníková ${ }^{1}\left(\mathbb{D}\right.$, Jana Čížková ${ }^{1}\left(\mathbb{D}\right.$, Veronika Zoulová ${ }^{1,2}$, Pavla Christelová $^{1}$ and Eva Hřibová ${ }^{1, *}$ (i) \\ 1 Institute of Experimental Botany of the Czech Academy of Sciences, \\ Centre of the Region Hana for Biotechnological and Agricultural Research, 77900 Olomouc, Czech Republic; \\ simonikova@ueb.cas.cz (D.Š.); cizkova@ueb.cas.cz (J.Č.); veronika.zoulova01@upol.cz (V.Z.); \\ christelova@ueb.cas.cz (P.C.) \\ 2 Department of Cell Biology and Genetics, Faculty of Science, Palacký University, \\ 77900 Olomouc, Czech Republic \\ * Correspondence: hribova@ueb.cas.cz; Tel.: +420-585-238-713
}

Citation: Šimoníková, D.; Čížková, J.; Zoulová, V.; Christelová, P.; Hřibová,

E. Advances in the Molecular

Cytogenetics of Bananas, Family

Musaceae. Plants 2022, 11, 482.

https: / / doi.org/10.3390/

plants11040482

Academic Editors: Bożena Kolano and Natalia Borowska-Zuchowska

Received: 23 December 2021

Accepted: 7 February 2022

Published: 11 February 2022

Publisher's Note: MDPI stays neutral with regard to jurisdictional claims in published maps and institutional affiliations.

Copyright: (C) 2022 by the authors. Licensee MDPI, Basel, Switzerland. This article is an open access article distributed under the terms and conditions of the Creative Commons Attribution (CC BY) license (https:// creativecommons.org/licenses/by/ $4.0 /)$.

\begin{abstract}
The banana is a staple food crop and represents an important trade commodity for millions of people living in tropical and subtropical countries. The most important edible banana clones originated from natural crosses between diploid Musa balbisiana and various subspecies of M. acuminata. It is worth mentioning that evolution and speciation in the Musaceae family were accompanied by large-scale chromosome structural changes, indicating possible reasons for lower fertility or complete sterility of these vegetatively propagated clones. Chromosomal changes, often accompanied by changes in genome size, are one of the driving forces underlying speciation in plants. They can clarify the genomic constitution of edible bananas and shed light on their origin and on diversification processes in members of the Musaceae family. This article reviews the development of molecular cytogenetic approaches, ranging from classical fluorescence in situ hybridization (FISH) using common cytogenetic markers to oligo painting FISH. We discuss differences in genome size and chromosome number across the Musaceae family in addition to the development of new chromosome-specific cytogenetic probes and their use in genome structure and comparative karyotype analysis. The impact of these methodological advances on our knowledge of Musa genome evolution at the chromosomal level is demonstrated. In addition to citing published results, we include our own new unpublished results and outline future applications of molecular cytogenetics in banana research.
\end{abstract}

Keywords: flow cytometry; chromosomes; fluorescence in situ hybridization; rRNA genes; DNA repeats; BAC clones; oligo painting; karyotyping

\section{Introduction}

Bananas (Musa ssp.) are large herbaceous plants grown in tropical and subtropical regions of Southeast Asia, Africa, and South America [1,2]. The banana is one of the most important crops cultivated worldwide, with annual production exceeding 150 million tons [3]. Cooking bananas serve as a staple food for millions of people. Moreover, bananas are one of the major export commodities of several developing countries, establishing them as an important element of national trades with a significant socioeconomic role.

The genus Musa, together with the two closely related genera Ensete and Musella, is a member of the monocotyledonous family Musaceae. Whereas Ensete and Musella are represented by only a few species, the genus Musa comprises about 75 species and numerous cultivated edible clones. Wild Musa species have traditionally been subdivided into four sections based on the basic chromosome number $(\mathrm{x})$ and a set of morphological descriptors $[4,5]$. These sections, namely Eumusa $(x=11)$, Rhodochlamys $(x=11)$, Australimusa $(x=10)$, and Callimusa $(x=9,10)$, were later supplemented by a fifth section Ingentimusa, which contains a single species Musa ingens $(x=7)[6]$. 
Modern cultivated bananas originated from natural inter- and intraspecific crosses between two wild diploid species of the Eumusa section: M. acuminata (A genome) and M. balbisiana (B genome). The evolution of some cultivars also involved crosses with $M$. schizocarpa (S genome) and Australimusa species (M. textilis, T genome), as revealed by molecular and cytogenetic methods [7-10]. A unique group of edible bananas is represented by Fe'i bananas found in the Pacific. These bananas are believed to originate from ancestors belonging to the Australimusa section [11,12]. However, most edible bananas are vegetatively propagated diploid $(\mathrm{AA}, \mathrm{AB})$, triploid (AAA, $\mathrm{AAB}$, or $\mathrm{ABB}$ ), or tetraploid clones classified in groups based on the relative proportion of respective $M$. acuminata and M. balbisiana genomes in their genotypes [13].

Cultivated bananas' complex mode of origin and the insufficient resolution of morphotaxonomic classification markers call for more detailed studies of the Musa genome on chromosomal and DNA levels. Moreover, information about chromosome structural changes could help banana breeders select appropriate parents during banana breeding processes. Traditional cytogenetic methods, such as for estimating genome size, ploidy, and chromosome counting, provide important information about the genome. Additional information on genomic constitution and large-scale chromosome structural changes that are associated with the evolution and speciation of bananas and their closely related genera can be obtained using molecular cytogenetics methods such as fluorescence in situ hybridization (FISH) and genomic in situ hybridization (GISH).

\section{Nuclear Genome of Bananas}

Nuclear genome size is one of the basic characteristics of a species and is commonly used in taxonomic studies of higher plants [14,15]. This value represents one copy of nuclear genetic information (equal to 1C) and can be expressed either in picograms (pg) or gigabase pairs (Gbp) using the formula of Doležel et al. [16], which considers 1 pg DNA to be equal to $0.978 \times 109 \mathrm{bp}$. A genome size of $\sim 0.6-0.64 \mathrm{pg} / 1 \mathrm{C}$ was estimated for $M$. acuminata and $\sim 0.55-0.57 \mathrm{pg} / 1 \mathrm{C}$ for $M$. balbisiana using flow cytometry, which clearly discriminated both species [8,17,18]. D'Hont et al. [19], Bartoš et al. [20], and Čížková et al. [21] further extended the knowledge on Musaceae nuclear DNA content by analyzing wild Musa and Ensete species. Their studies showed that the genome sizes of Eumusa and Rhodochlamys accessions overlap, ranging from 0.61 to $0.69 \mathrm{pg} / 1 \mathrm{C}$ in Eumusa and from 0.6 to $0.66 \mathrm{pg} / 1 \mathrm{C}$ in Rhodochlamys. Australimusa species were characterized by genome sizes varying between 0.65 and $0.77 \mathrm{pg} / 1 \mathrm{C}$. The highest nuclear DNA content and interspecific variation of this feature were observed in species belonging to the Callimusa section, with values ranging from 0.7 to $0.89 \mathrm{pg} / 1 \mathrm{C}$. A strong negative correlation between the $2 \mathrm{n}$ chromosome number and nuclear DNA content was found within Musa species [21].

The genome size was also estimated for Ensete gilletii [20] and Musella lasiocarpa (Figure 1A, unpublished) to complement our knowledge of nuclear genomes in all three genera. Representatives of two genera closely related to genus Musa had nuclear DNA contents similar to the Eumusa and Rhodochlamys species. E. gilletii was characterized by a genome size of $0.61 \mathrm{pg} / 1 \mathrm{C}$ [20], and an even lower value $(0.59 \mathrm{pg} / 1 \mathrm{C})$ was estimated for M. lasiocarpa (Figure 1A, unpublished). 


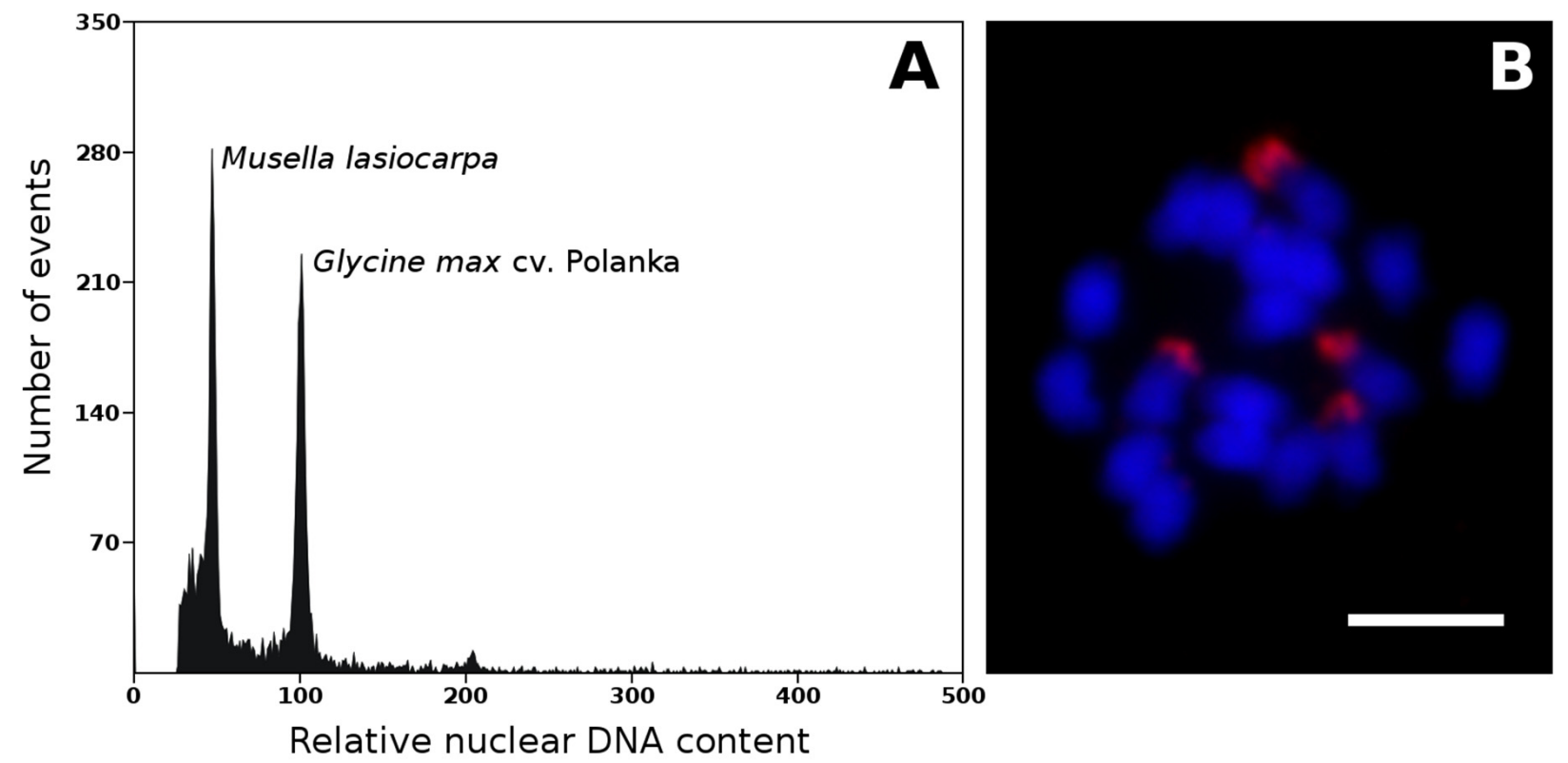

Figure 1. Estimation of nuclear genome size and chromosome number in Musella lasiocarpa. (A) Histogram of relative nuclear DNA content obtained after flow cytometric analysis of propidium iodide-stained G1 nuclei of $M$. lasiocarpa $(2 \mathrm{C}=1.174 \mathrm{pg})$ and Glycine max $(2 \mathrm{C}=2.5 \mathrm{pg})$, which served as the internal reference standard. Measurements were performed according to Bartoš et al. [20]. (B) mitotic metaphase chromosomes of $M$. lasiocarpa $(2 n=2 x=18)$. The chromosomes were counterstained with DAPI (blue); the probe specific to $45 \mathrm{~S}$ rDNA sequence (red) was localized to secondary constrictions. Probe specific to $45 \mathrm{~S}$ rDNA was prepared according to Čížková et al. [8]. Bars correspond to $5 \mu \mathrm{m}$.

The low level of divergence in genome sizes within species of the Eumusa section containing diploid, triploid, and tetraploid edible banana cultivars permit the use of flow cytometric analysis for rapid identification of ploidy levels. This approach is based on nuclei isolation from a small part of banana leaf tissue used in combination with an external or internal standard. In the case of bananas, previously characterized diploid M. acuminata or M. balbisiana genotypes can serve as standards for ploidy estimation of economically important intra- and interspecific banana hybrid clones that originated from natural crosses between these two diploid species or during banana breeding programs. As shown in the study by Christelová et al. [9], ploidy level estimation using flow cytometry can be assessed using chicken red blood cell nuclei (CRBC) as an internal reference standard. The ratio between the relative DAPI fluorescence intensity of G1-phase nuclei from accessions of the Musa section and CRBC nuclei is $\sim 0.5$ for diploid plants, $\sim 0.75$ for triploid plants, and 1 for tetraploid plants (Figure 2, unpublished). Aneuploidy may be the case for plants with ploidy levels deviating from regular ratios. Roux et al. [22] successfully applied flow cytometry to detect aneuploidy in bananas. On the other hand, their study also revealed that this method is laborious and inconvenient for large-scale screening. 


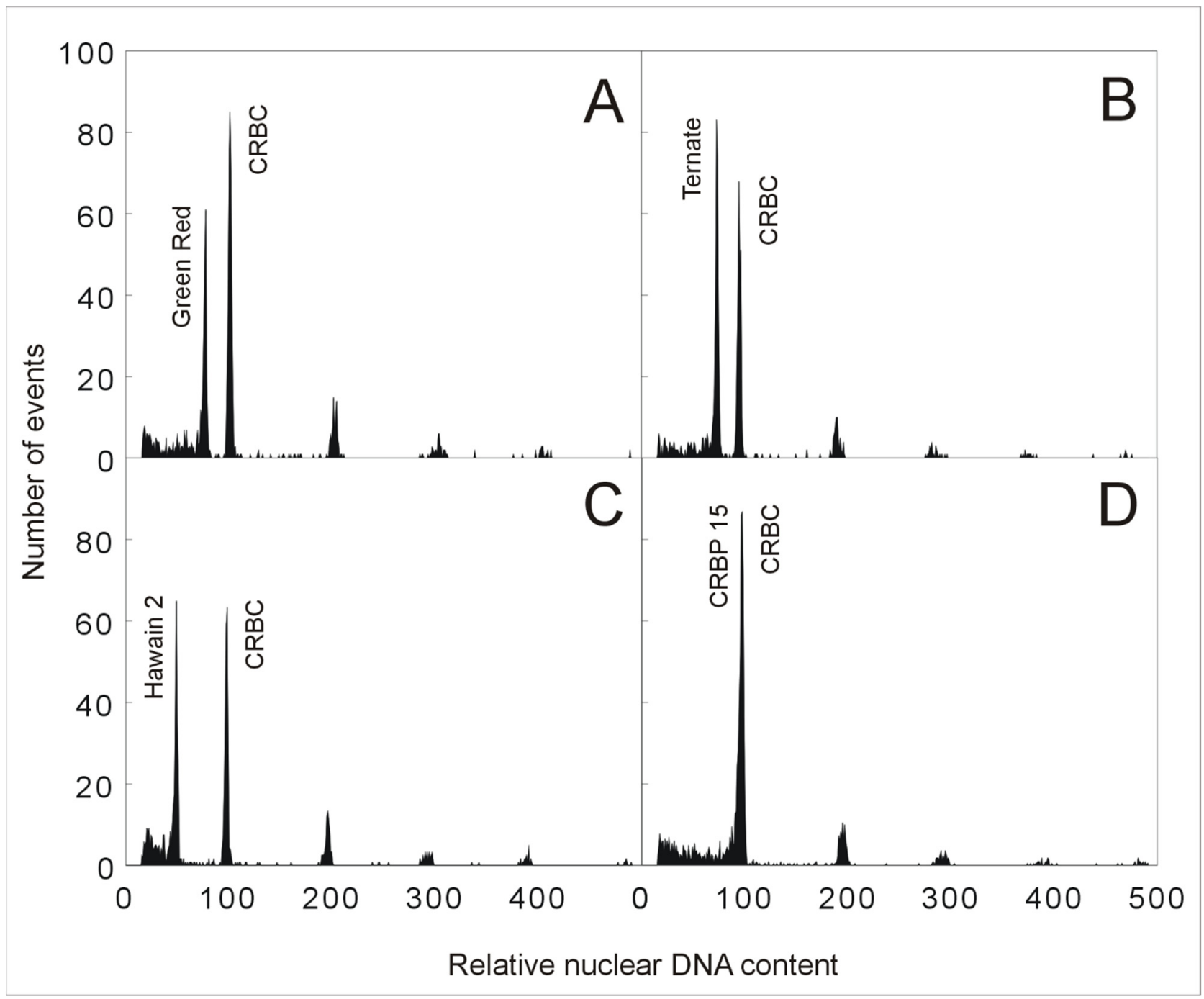

Figure 2. Determination of Musa ploidy level by flow cytometry. Histograms of relative nuclear DNA content obtained after flow cytometric analysis of DAPI-stained nuclei isolated from various accessions of Musa, and chicken red blood cell nuclei (CRBC) served as the internal reference standard. (A) triploid accession 'Green Red' (genomic constitution AAA; peak ratio 0.75); (B) triploid accession 'Ternate' (genomic constitution AAB; peak ratio 0.76); (C) diploid M. acuminata 'Hawain 2' (genomic constitution AA; peak ratio 0.51); (D) tetraploid accession 'CRBP 15' (genomic constitution AAAB; peak ratio 1). Measurements were performed according to Christelová et al. [9].

\section{Chromosome Number and Structure}

A small genome of bananas (genus Musa) and related genera are divided into a relatively high number of morphologically similar chromosomes. The basic chromosome number (x) in species of the Musaceae family varies from 7 to 11 (Figure 3). Closely related genera Ensete and Musella are diploid with a basic chromosome number $\mathrm{x}=9$. Basic chromosome number and plant morphology are traditionally used characteristics for taxonomically classifying members of the Musa genus, which is divided into four sections: Eumusa $(x=11)$, Rhodochlamys $(x=11)$, Australimusa $(x=10)$, and Callimusa $(x=7$, 9, 10) [4] (Figure 3). Musa ingens, assigned to the Callimusa section, represent a single species with the lowest basic chromosome number $(x=7)$. Most edible banana clones originated as a result of natural intra- and interspecific hybridization between subspecies of $M$. acuminata (A genome) and $M$. balbisiana (B genome) within section Eumusa and contain $22(2 n=2 x=22$, diploids), $33(2 n=3 x=33$, triploids), and $44(2 n=4 x=44$, tetraploids) chromosomes in somatic cells. Another small but nutritionally valued group 
of edible banana clones, known as Fe'i bananas, is derived from M. maclayi, a member of the Australimusa section. They are diploids and have maintained the basic chromosome number characteristic of representatives of the Australimusa section $(x=10)[1,20,23]$.

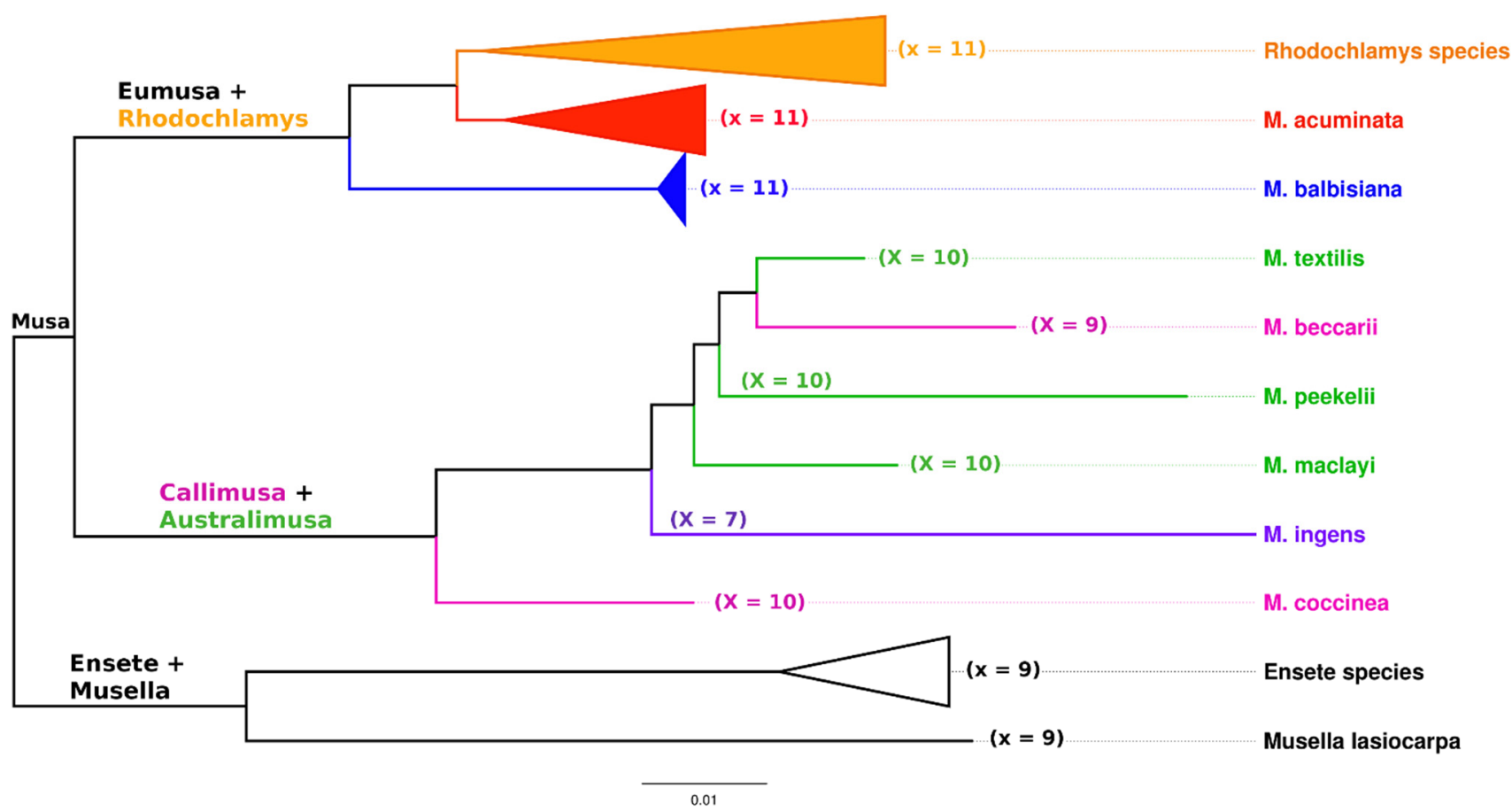

Figure 3. Phylogenetic tree of Musaceae family members. The tree is constructed from ITS1-ITS2 sequence regions of ribosomal DNA using the BioNJ method implemented in SeaView [24]. Names of the four sections of Musa, species belonging to the corresponding section, and their basic chromosome number (x) are printed in different colors: Eumusa section (red), resp. (blue), Rhodochlamys section (orange), Callimusa section (pink), and Australimusa section (green). In addition, M. ingens from the Ingentimusa section is included in the figure (purple).

Banana mitotic chromosomes are usually 1-2 $\mu \mathrm{m}$ long meta- or submetacentric and have similar morphology (Figure 4A-D). Differences in chromosome morphology were observed in species of the genera Ensete and Musella and section Callimusa. Although some of their mitotic metaphase chromosomes are larger $(1-4 \mu \mathrm{m})$, it is impossible to unambiguously identify all individual chromosomes using standard chromosome features, such as chromosome length and position of centromere and secondary constriction(s) [8,20,21,25-27]. In addition to the small size of mitotic metaphase chromosomes, the high level of chromatin condensation also complicates their identification. Similarly, secondary constriction does not serve as a good morphological marker for chromosome identification in Musa. Although secondary constrictions are easily localized in Musa species (Figure 4A-D) [25], they readily break away from the rest of the chromosome during chromosome spread preparation (Figure 4D). In more recent studies, secondary constrictions separated from mother chromosomes were considered supernumerary small chromosomes [28,29]. In analyzed accessions within the sections Eumusa, Rhodochlamys, Australimusa, and Callimusa, the number of secondary constrictions corresponds to their ploidy levels (Figure 4A-D) $[8,25,26]$. A higher variability (higher number) of secondary constrictions was observed in species from the genera Ensete [20] and Musella (Figure 1B, unpublished). 

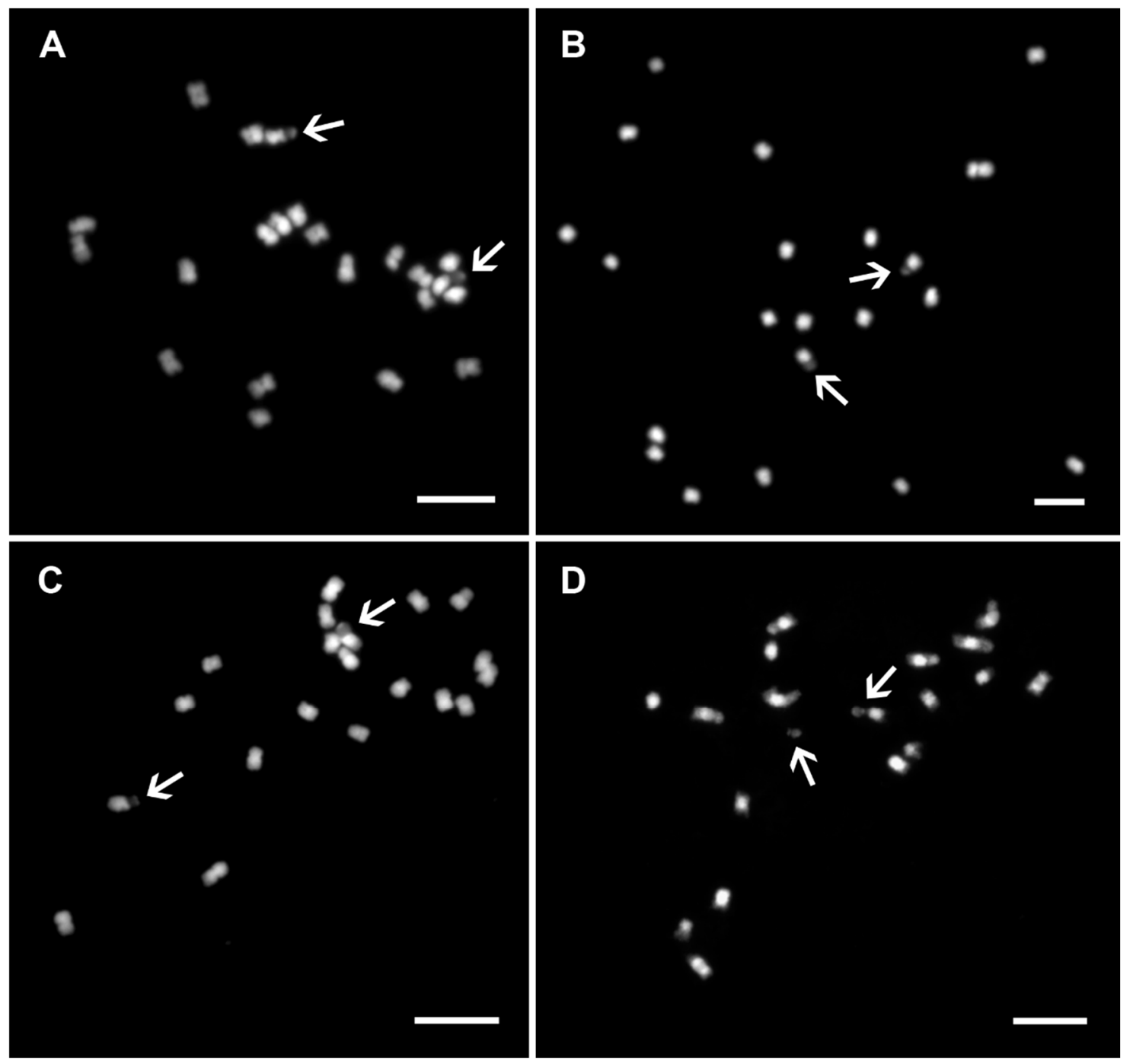

Figure 4. Mitotic chromosomes of genus Musa. Mitotic metaphase plates of (A) Musa acuminata ssp. burmannicoides ITC0249 ( $2 \mathrm{n}=2 \mathrm{x}=22)$ from Eumusa section; (B) M. laterita ITC1575 $(2 \mathrm{n}=2 \mathrm{x}=22)$ from Rhodochlamys section; (C) M. maclayi ITC1207 $(2 \mathrm{n}=2 \mathrm{x}=20)$ from Australimusa section; and (D) M. beccarii ITC1070 $(2 \mathrm{n}=2 \mathrm{x}=18)$ from Callimusa section. The chromosomes were stained with DAPI, and the images are shown in white pseudo-color. Arrows indicate secondary constrictions. One secondary constriction broke from the rest of the chromosome as shown in (D). Bars correspond to $5 \mu \mathrm{m}$.

The development of chromosome banding techniques in the 1970s and 1980s [30-32] was effective for chromosome identification in humans and some animals. Unfortunately, banding techniques were successful only in the case of a few plant species (e.g., species of the family Poaceae [33-35] or Lilium [36]), which are commonly characterized by large genomes containing numerous repeat-rich regions. To identify individual chromosomes in most plant species, including those of Musaceae, molecular cytogenetics techniques that utilize specific chromosome landmarks localized by in situ hybridization must be applied.

\section{Molecular Cytogenetics of Musaceae}

The development of in situ hybridization and, particularly, fluorescence in situ hybridization (FISH) [37] has enabled the detailed analysis of genome and chromosome structure. FISH is a suitable method for localizing fluorescently labeled DNA sequences (probes) onto mitotic or meiotic chromosomes or in the nuclei and provides important insights into the long-range organization of DNA sequences in the genomes [37,38]. In 
many plant species, including bananas, FISH presents the only possibility for discriminating individual chromosomes and generating molecular karyotypes. The potential of FISH for karyotyping depends on the availability of probes that produce chromosome-specific labeling patterns.

Typical chromosomal loci largely used as FISH probes are represented by tandem repetitive arrays of $5 \mathrm{~S}$ and $45 \mathrm{~S}$ rRNA genes and satellite DNA sequences whose chromosome location is species-specific (e.g., [25,39-42]). Another extensively employed probe types are BAC (bacterial artificial chromosome) clones bearing large single- and low-copy DNA sequences $[43,44]$ or certain mobile repetitive elements dispersed on all chromosomes but provide signals on specific chromosomal regions, e.g., in centromeres [8,45-47]. Recently, short single-copy sequences, mainly derived from genic regions (1.5-5 kb long), were also successfully used for karyotyping in some plant species, e.g., wheat, barley, and Agropyron spp. [48-50]. However, short single-copy sequences were not used as probes for FISH due to the high level of mitotic Musa chromosome condensation.

\subsection{Identification of Chromosomes by FISH}

Even though species of the Musaceae family have small genomes, only a few DNA sequences have proved useful in studying the organization of nuclear genomes at the cytogenetic level to date (Figure 5A-K). In the first studies, probes specific to $5 \mathrm{~S}$ and $45 \mathrm{~S}$ rDNA sequences were used to identify mitotic chromosomes of progenitors of the most popular edible banana clones-M. acuminata and M. balbisiana [25,26]. Genes for 45S rRNA were localized onto a secondary constriction (nucleolar organizing region, NOR) for one pair of chromosomes in both species, and differences were found in the 5S rDNA loci between M. acuminata and M. balbisiana. Since 5S and 45S rRNA genes occur in thousands of tandemly organized copies, usually localized in separate loci within the genomes, they serve as popular cytogenetic landmarks in many plant species and are still widely used, e.g., in Aegilops spp. [51], Brassica spp. [52] or Fragaria spp. [53]. The results from further cytogenetic studies of Musaceae have contributed to our knowledge on the organization of rRNA genes in the genomes of more than 60 accessions, including various Musa species, edible banana cultivars, and of the related genera Ensete and Musella [8,10,20,21,25,26,54].

Genes coding for a large rRNA subunit (45S) were localized to the NOR region on one chromosome pair of diploid, three chromosomes of triploid, and four chromosomes of tetraploid representatives in the Eumusa section (Figure 5H) $[8,20,25,26]$. Species of the closely related Rhodochlamys section contain one or two pairs of mitotic metaphase chromosomes with 45S rDNA signals localized in secondary constrictions; representatives of the Australimusa section contained one chromosome pair carrying NOR [20,21]. The situation within the Calimusa section is more variable, reflecting the high genetic species diversity in which there are even differences in the number of chromosomes [20,21]. Most Callimusa species have 20 mitotic chromosomes with two $45 \mathrm{~S}$ rDNA loci localized in secondary constrictions. On the other hand, $M$. borneensis $(2 n=2 x=20)$ was found to contain five $45 \mathrm{~S}$ rDNA loci, with two localized in secondary constrictions; however, the other two signals were large interstitial clusters on other chromosomes. The fifth weak signal was detected in the telocentric region of another chromosome [21]. A similar distribution of $45 \mathrm{~S}$ rDNA loci was also observed in $M$. beccarii with $2 n=2 x=18$, where two loci were located in secondary constrictions and another four strong interstitial clusters were located on other chromosomes [20,21]. Despite having the same basic number of chromosomes $(2 \mathrm{n}=2 \mathrm{x}=18)$, the phylogenetically related genus Ensete even contains eight $45 \mathrm{~S}$ rDNA loci in secondary constrictions located at the chromosomal ends, whereas Musella genus contains four loci of $45 \mathrm{~S}$ rRNA genes (Figure 1B, unpublished). 


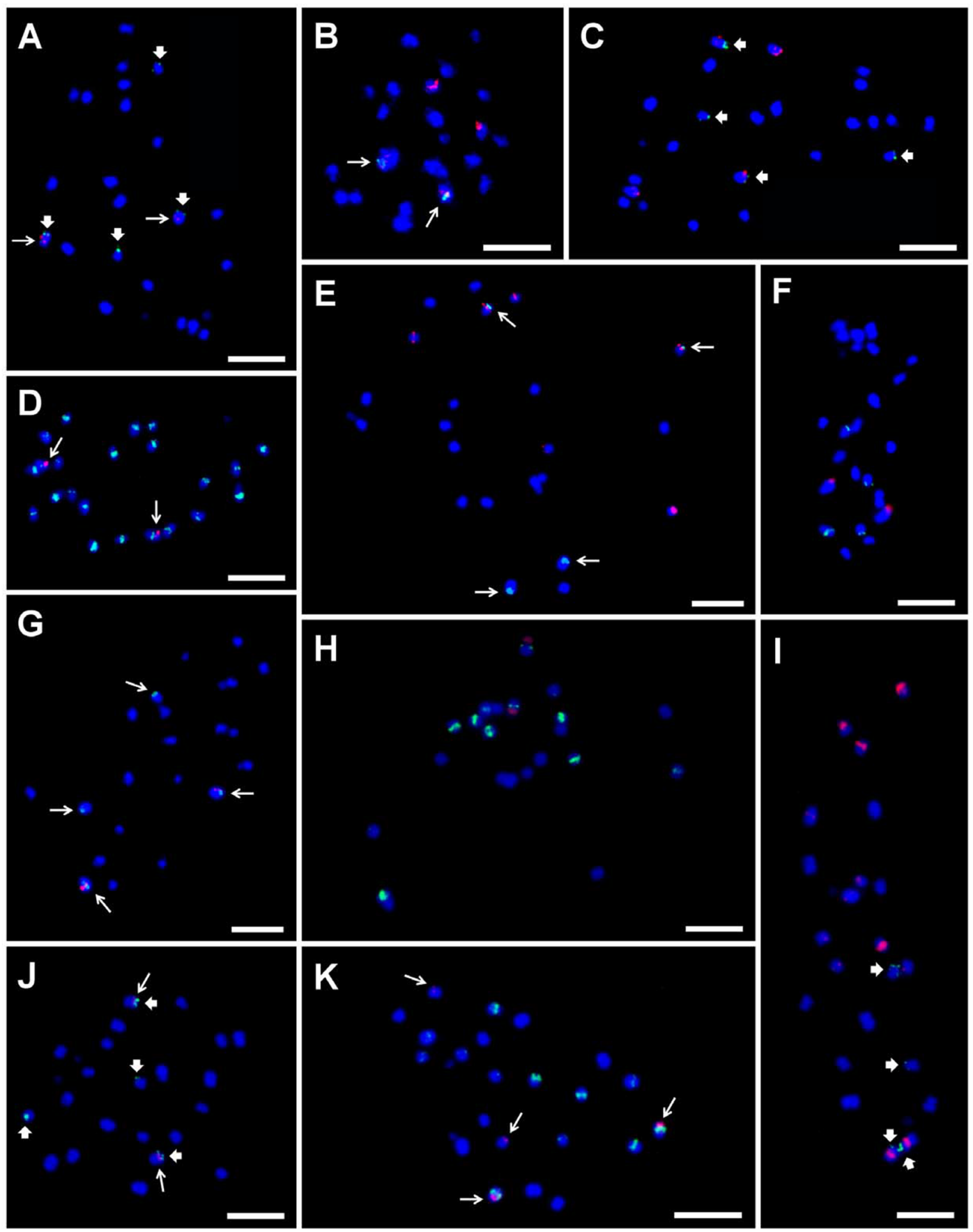

Figure 5. Examples of the genomic distribution of DNA satellites, BAC clone, LINE element, and rDNA as determined in mitotic metaphase chromosomes of diploid Musa accessions after FISH. Satellite repeat sites CL18 and CL33 probe hybridization are marked by long and thick arrows, respectively. (A) CL18 (red) and CL33 (green) on 'Long Tavoy' chromosomes; (B) 5S rDNA (red) and CL18 (green) on 'Maia Oa' chromosomes; (C) 5S rDNA (red) and CL33 (green) 'Long Tavoy' chromosomes; (D) CL18 (red) and LINE element (green) on 'Tuu Gia' chromosomes; (E) 5S rDNA (red) and CL18 (green) on 'Pisang Klutuk Wulung' chromosomes; (F) BAC clone 2G17 (red) and 5S rDNA (green) on chromosomes of 'Cameroun'; (G) BAC clone 2G17 (red) and CL18 (green) on 'Tani' chromosomes; (H) 45S rDNA (red) and 5S rDNA (green) on M. schizocarpa ITC 0560 chromosomes; (I) 5S rDNA (red) and CL33 (green) on M. schizocarpa ITC 1002 chromosomes; (J) CL18 (red) and CL33 (green) on M. schizocarpa ITC 1002 chromosomes; (K) CL18 (red) and 5S rDNA (green) on M. schizocarpa ITC 1002 chromosomes. Chromosomes were counterstained with DAPI (blue). Bars correspond to $5 \mu \mathrm{m}$. Retrieved from Čížková et al. [8]. 
A larger variation was observed in $5 \mathrm{~S}$ rDNA loci, localized on chromosomes other than those carrying $45 \mathrm{~S}$ rRNA genes in NOR (Figure $5 \mathrm{H})[8,10,20,21,25,26,54]$. The only exception was observed in $M$. beccarii and M. borneensis, in which two of the 5S rDNA loci co-localized with interstitially localized $45 \mathrm{~S}$ rRNA genes [21]. In contrast to most $45 \mathrm{~S}$ rDNA location, odd numbers of $5 \mathrm{~S}$ rDNA loci were observed in more Musa representatives, e.g., in M. acuminata 'Pisang Mas', 'Pisang Lilin', 'Niyarma Yik', and the hybrid 'TMPx $8084-1^{\prime}[20,21,25,26]$.

Given the lower chromosome number, one may speculate that the interstitial clusters of $45 \mathrm{~S}$ rDNA are a remnant of chromosome reshuffling accompanying evolution. The odd number of $45 \mathrm{~S}$ and $5 \mathrm{~S}$ rDNA loci could indicate structural chromosome heterozygosity, suggesting the hybrid origin of some Musa species. In this context, the presence of odd numbers of $5 \mathrm{~S}$ rDNA in interspecific hybrid clones between M. acuminata and M. schizocarpa [21] may be interpreted as evidence for such a hypothesis. On the other hand, unstable additional chromosome fragments may cause variability in rDNA loci, as shown in banana hybrid clones, e.g., TMPx 8084-1 (AA), obtained from a cross between wild diploid genotype M. acuminata 'Calcutta 4 ' and a triploid plantain [26]. However, the 5S rDNA loci contained a low number of repetitive units, implying that hybridization signals below the detection limit of FISH cannot be overlooked as a causal agent for the odd number of $5 \mathrm{~S}$ rDNA loci [21].

Given the high basic chromosome number of most Musaceae representatives, colocalization of $5 \mathrm{~S}$ and $45 \mathrm{~S}$ rDNA loci did not permit chromosome identification. Therefore, other types of repetitive DNA sequences and BAC clones were employed to generate molecular karyotypes in Musaceae. Former studies focused on isolating and characterizing different types of repetitive DNA sequences, mainly tandem organized repeats, which serve as good cytogenetic markers in plant studies, e.g., in wheat [55,56], Aegilops spp. [57], or Agropyron cristatum [50]. Balint-Kurti et al. [58] as well as Valárik et al. [27] and Hřibová et al. [59] succeeded in identifying one sequence region of retrotransposon monkey and repetitive elements named Radka1 and Radka 7, both of which localized exclusively to NOR and co-localized with the $45 \mathrm{~S}$ rDNA loci. Unfortunately, further analysis of the repetitive parts of banana and enset genomes by low coverage next-gen sequencing [60] provided only two candidates for tandem repeats that performed well as cytogenetic markers. A more complex analysis of the banana repeatome performed in five Musa and one Ensete species [60,61] confirmed the two main satellite DNA sequences, and these were later successfully used for karyotyping in Musa (Figure 5) [8,10,54]. However, a more detailed characterization of the repeats led to identification of a retrotransposon MusA1 and a LINE element, predominantly localized in the centromeric region and further successfully used as centromeric probes in Musa cytogenetic studies (Figure 5D) [8,10,62].

The traditionally employed chromosome-specific set of landmarks also covers singleand low-copy BAC (bacterial artificial chromosome) clones, which were used to identify specific chromosomes in several plant species [63-66]. The BAC-FISH was largely unsuccessful in bananas when most low-copy BAC clones identified after a colony array of BAC libraries provided dispersed signals in the genome, even after their subcloning [46]. Only a few BAC clones were mapped onto banana mitotic and meiotic chromosomes as chromosome specific (Figure 5G) [8,46,67,68]. However, new BAC clones selected from BamH1 and HindIII BAC libraries of M. acuminata ssp. malaccensis 'DH Pahang' [69] were used to validate chromosomal translocations detected in silico [70,71].

FISH probes derived from BAC clones or repetitive DNA sequences have been widely applied in many species; however, preparation is time consuming. Moreover, these probes are inefficient in plant species with many chromosomes or when the chromosome size is an issue $[38,45]$. Altogether, standard cytogenetic landmarks, including satellite DNA and other repetitive DNA sequences or single- and low-copy BAC clones, did not result in the unambiguous identification of all banana chromosomes at the cytogenetic level. 


\subsection{Integrated Karyotyping Using Oligo Painting FISH}

The possibility to design probes capable of distinguishing between individual chromosomes and comparative karyotype analysis in plant species was recently achieved using oligo painting FISH. This method is based on the identification of large sets of unique oligomer sequences (up to $50 \mathrm{nt}$ long) specific to selected genome regions, e.g., chromosomes (reviewed in Jiang [72]).

Chromosome-scale assemblies or at least draft genome assemblies are used for in silico identification of all possible unique oligomers that can be used as probes for FISH (e.g., $[73,74])$. Computational analysis and in silico selection of oligomers covering specific genome regions can be performed using Chorus software, specifically created for this approach [75] or other bioinformatic tools (reviewed in Liu and Zhang [76]). Large sets of oligomers are then synthesized in parallel, labeled directly by fluorophores or indirectly by haptens, and used for in situ hybridization. Oligo painting FISH has successfully been used to analyze the genome structure in many plant species, including Poaceae species [77-84], Solanum spp. [85,86] or subtribe Phaseolineae [87].

In bananas, oligo painting FISH was established by Šimoníková et al. [54], who created chromosome arm-specific painting probes based on the reference genome sequence of doubled haploid M. acuminata ssp. malaccensis 'DH Pahang' v.2 (A genome, $\mathrm{x}=11$ ) [88]. In their study, a set of nineteen oligo painting probes was successfully hybridized to mitotic chromosomes of $M$. acuminata, and two closely related species, $M$. balbisiana (B genome, $\mathrm{x}=11$ ) and $M$. schizocarpa (S genome, $\mathrm{x}=11$ ), that participated in the origin of most edible banana clones. For the first time in Musa cytogenetics, all individual chromosomes were unambiguously distinguished, and molecular karyotypes of the three Musa species were established by combining oligo painting probes and previously described cytogenetic markers [54]. Oligo painting probes facilitated the anchoring of pseudomolecules to chromosomes and identifying large translocation events in M. balbisiana. Moreover, the density of these oligo painting probes was sufficient for analyzing less condensed meiotic pachytene chromosomes (Figure 6A,B), thereby opening another important future application for detailed analysis (or confirmation) of chromosomal rearrangements detected in silico, e.g., in draft genome assemblies created by long-read sequencing technologies.
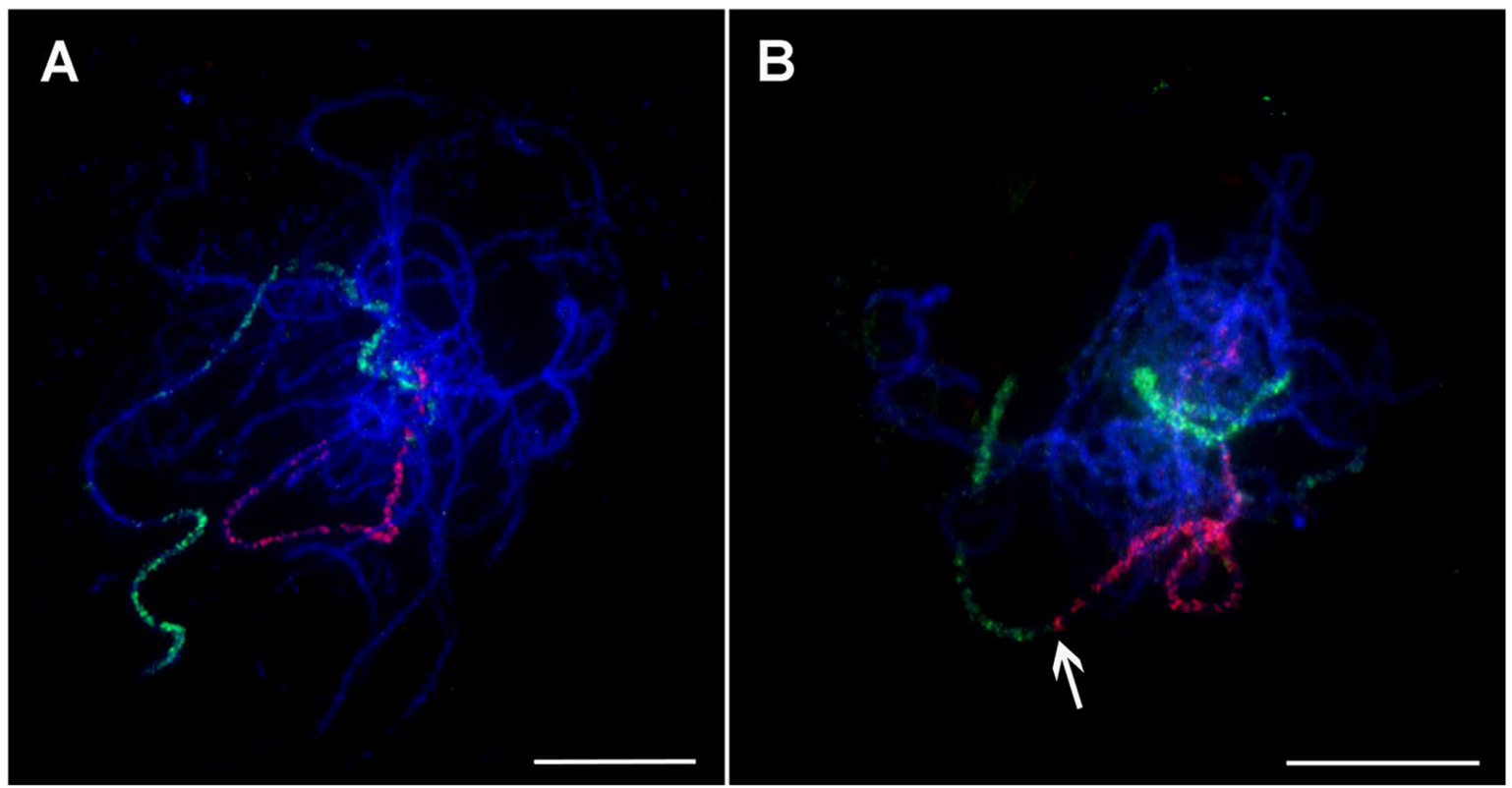

Figure 6. Oligo painting FISH on meiotic pachytene chromosome spreads of Musa. (A) M. acuminata ssp. malaccensis 'Pahang' ( $2 \mathrm{n}=2 \mathrm{x}=22$, AA; chromosome 1 in red, chromosome 4 in green); (B) $M$. balbisiana 'Tani' ( $2 \mathrm{n}=2 \mathrm{x}=22$, BB; chromosome 1 in red, chromosome 3 in green). Chromosomes were counterstained with DAPI (blue). Arrows point to the region translocated from chromosome 3 to chromosome 1 in M. balbisiana. Bars correspond to $10 \mu \mathrm{m}$. Retrieved from Šimoníková et al. [54]. 
Afterward, the chromosome-arm specific oligo painting probes were applied to study genome structure in twenty representatives of genus $M u s a$, covering edible banana clones and their probable progenitors [89]. This method was used to detect many chromosomal translocations that were specific to individual subspecies of M. acuminata. Interestingly, an odd number of translocation events was noticed in the genomes of some analyzed wild diploid Musa species (e.g., M. acuminata ssp. siamea, and ssp. burmannica), indicating their hybrid origin and the structural heterozygosity of their genomes. Therefore, oligo painting FISH was shown to be useful for identifying edible banana clone progenitors and brought new insights into their evolution. As an example, oligo painting FISH revealed a reciprocal translocation between chromosomes 3 and 8 in two chromosome sets in triploid East African highland banana (EAHB) clone 'Imbogo' (Figure 7C,D). The same translocation was detected in the homozygous state of M. acuminata ssp. zebrina 'Maia Oa' (Figure 7A,B). Thus, M. acuminata ssp. zebrina has been acknowledged as one of the progenitors of East African highland bananas [89].

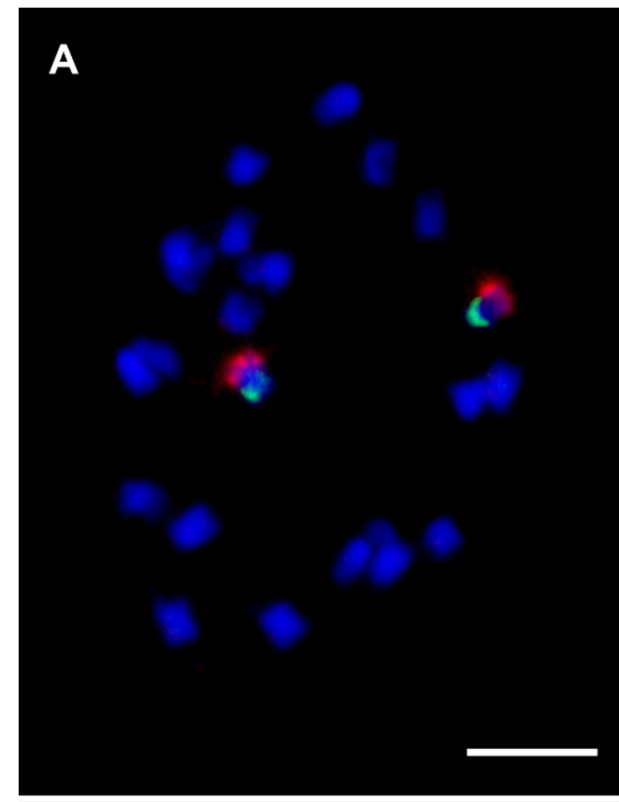

B M. acuminata ssp. zebrina (AA)

$\begin{array}{lllllllllll}1 & 2 & 3 & 4 & 5 & 6 & 7 & 8 & 9 & 10 & 11\end{array}$

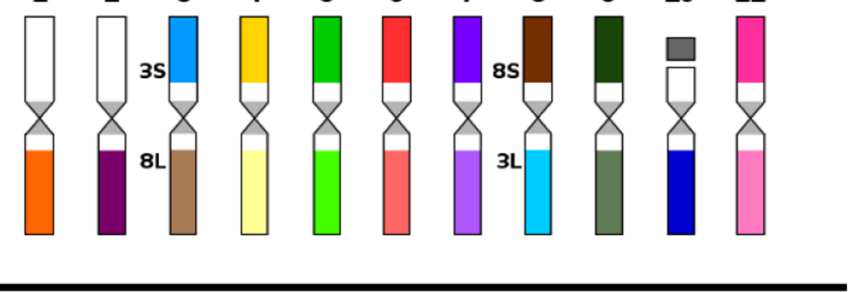

$\mathbf{D}$

Mutika/Lujugira clone 'Imbogo' (AAA)
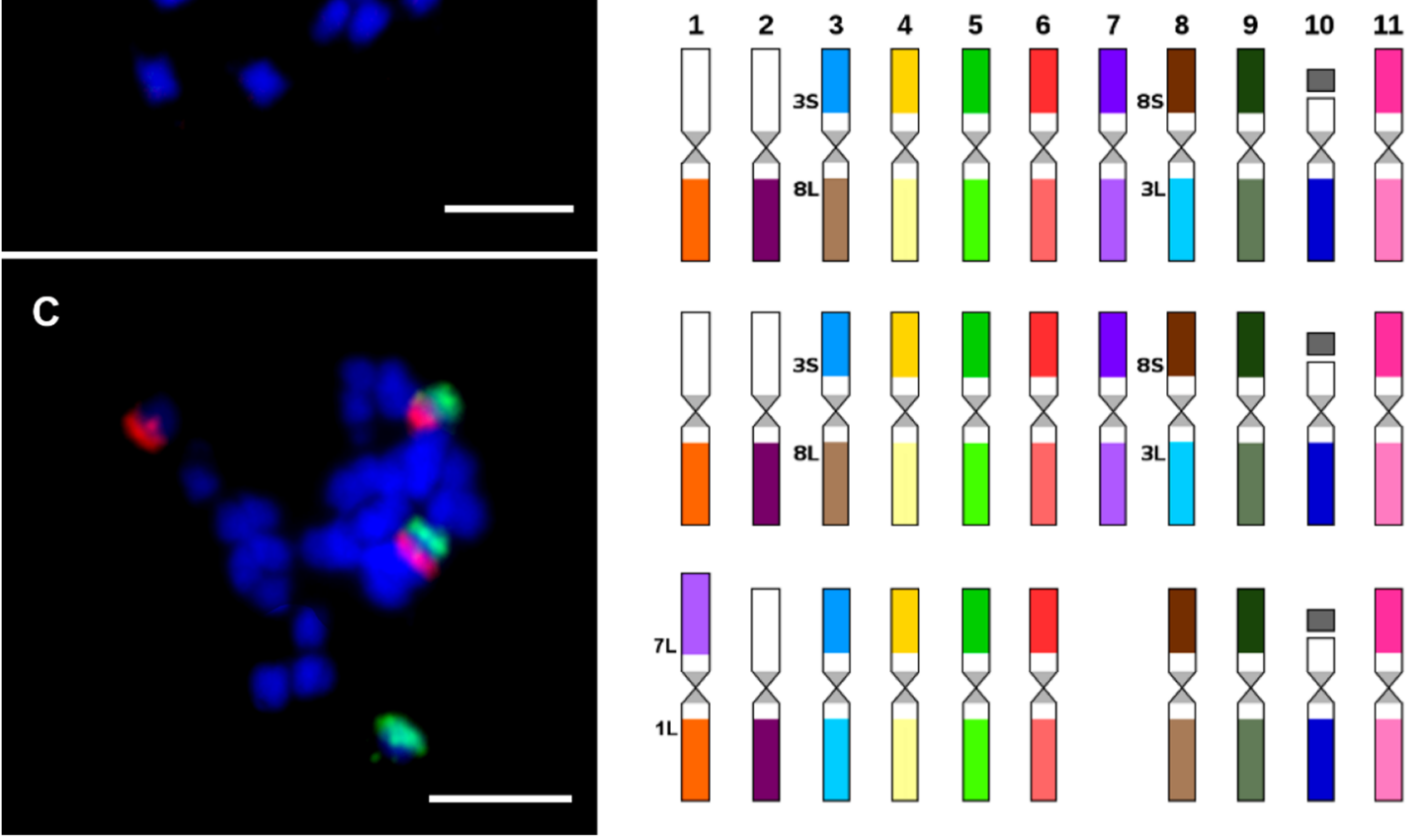

Figure 7. Oligo painting FISH on mitotic metaphase plates of two Musa accessions (A) M. acuminata ssp. zebrina 'Maia Oa' $(2 \mathrm{n}=2 \mathrm{x}=22$, AA; long arm of chromosome 3 in red, short arm of chromosome $8 \mathrm{~S}$ green; (B) aneuploid East African Highland banana (EAHB) clone 'Imbogo' $(2 \mathrm{n}=3 \mathrm{x}-1=32$, AAA; long arm of chromosome 3 in green, short arm of chromosome 8 in red; (C) idiogram of $M$. acuminata ssp. zebrina 'Maia Oa'; (D) idiogram of aneuploid East African Highland banana (EAHB) clone 'Imbogo'. Chromosomes were counterstained with DAPI (blue). Bars correspond to $5 \mu \mathrm{m}$. Idiograms were retrieved from Šimoníková et al. [89]. 


\subsection{Analysis of Genome Constitution in Banana Hybrid Clones}

Many plant species and economically important cultivars, including edible banana clones, have originated from intra- or interspecific crosses. Thus, one of the important tasks is to discover the genomic constitution of interspecific hybrid species by identifying parental chromosomes and their recombination products at the cytogenetic level, which can be achieved by applying genomic in situ hybridization (GISH). Compared to FISH, where specific DNA sequences localize to genomes, GISH uses total genomic DNA to probe chromosomes. GISH was successfully used to analyze chromosome constitution and meiotic pairing in different natural or artificial plant hybrids and even allopolyploids, including representatives of the Poaceae, Brassicaceae, and Solanaceae families [90-95]. During the GISH procedure, the total genomic DNA of one (putative) progenitor serves as a probe, and genomic DNA isolated from other (putative) progenitors of the studied hybrid or allopolyploid specimen serve either as blocking DNA, additionally used in excess amounts relative to the probe, or as a second-color probe. The probe/blocking DNA ratio is species-specific and depends on the degree of homology between the progenitors of the hybrid or allopolyploid species [90,96,97].

The same applies to banana hybrid clones, where the success of GISH experiments is highly dependent on phylogenetic relatedness and the variability of the genomes that gave rise to the hybrids. The most important interspecific banana cultivars originated by crosses between two closely related wild species M. acuminata (A genome) and M. balbisiana (B genome), both representatives of the Eumusa section (Figure 3). GISH experiments performed on $\mathrm{A} \times \mathrm{B}$ banana hybrids resulted in signals covering all chromosomes (with different intensities) in the hybrid genomes. Moreover, the signals covered only pericentromeric regions and partially distal chromosome parts [97-99]. The labeling pattern in $\mathrm{A} \times \mathrm{B}$ banana hybrids did not visualize distal and subtelomeric chromosome parts often involved in translocation events. Thus, it was also impossible to detect recombination events between interspecific chromosomes [97-99]. These findings demonstrate the limits of the GISH technique for analyzing the genomic constitution of $\mathrm{A} \times \mathrm{B}$ banana hybrid clones.

By comparison, $\mathrm{A} \times \mathrm{T}$ banana hybrid clones originate from crosses between distantly related species M. acuminata (A genome, Eumusa section) and M. textilis (T genome, Australimusa section). In these banana hybrids, GISH clearly labeled chromosomes specific to A and T subgenomes [97], suggesting the presence of more differentiated DNA repeat types between these two species [61]. FISH experiments were conducted with the two Radka DNA sequences (Radka5 and Radka6) [27] using genomes of $\mathrm{A} \times \mathrm{T}$ banana hybrid clones to demonstrate the main contribution of specific DNA repeats to GISH signals. Radka DNA sequences were initially isolated from M. acuminata and cytogenetically localized to all mitotic chromosomes in M. acuminata and M. balbisiana [27]. These two short parts (742, resp. $193 \mathrm{nt}$ long) of banana retroelements were determined to be specific to Eumusa species, and FISH analysis with probes derived from Radka5 and Radka6 in the genome of $\mathrm{A} \times \mathrm{T}$ banana hybrids resulted in signals specific (visible) to chromosomes originating from the A subgenome progenitor (Figure 8A,B, unpublished). Compared with $\mathrm{A} \times \mathrm{B}$ banana hybrid clones, whose progenitors are more closely related and share a large proportion of similar DNA sequences, progenitors of $\mathrm{A} \times \mathrm{T}$ banana hybrid clones are more phylogenetically distant. Only a short part of the repetitive elements was sufficient for visualizing chromosomes of one particular progenitor by in situ hybridization. 

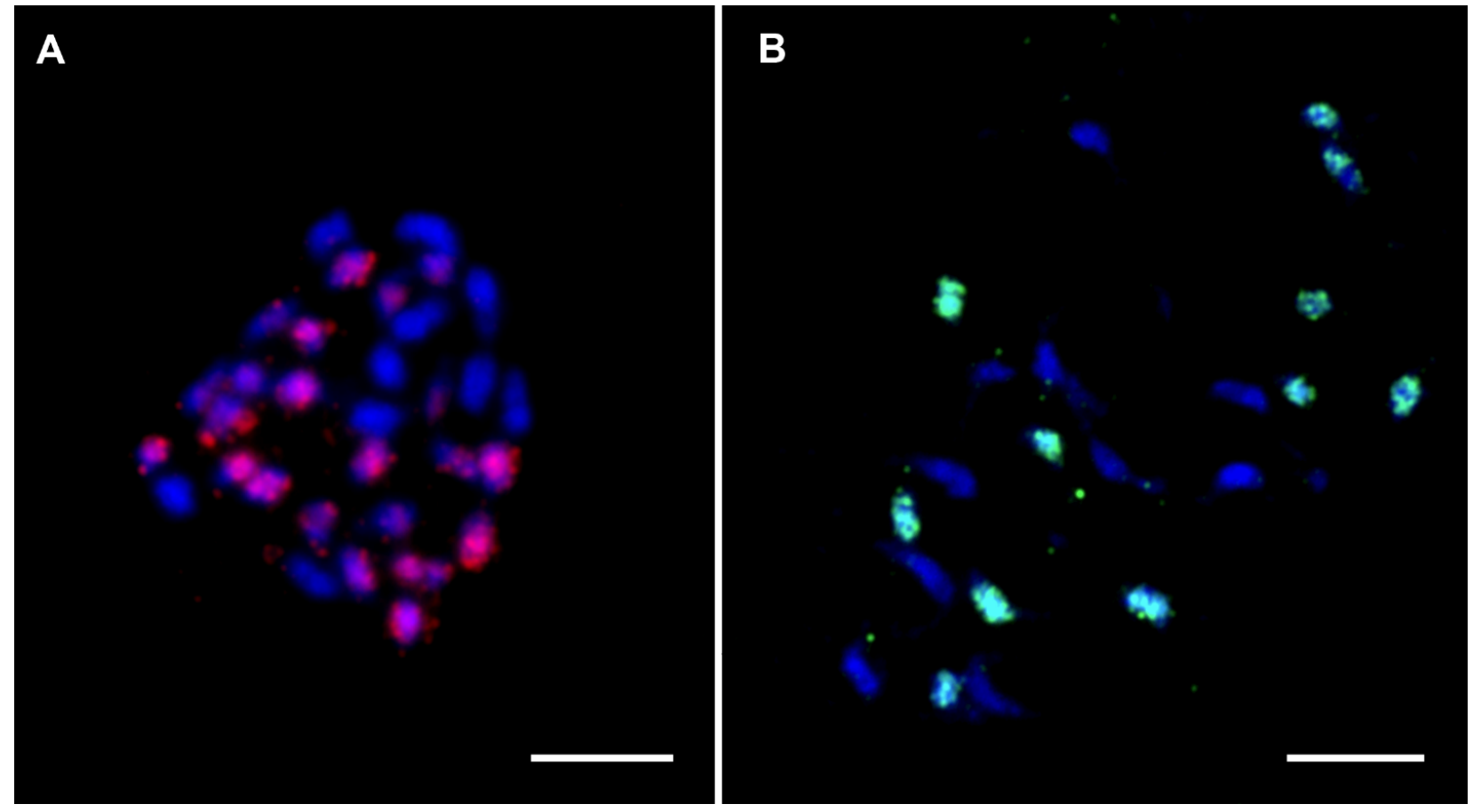

Figure 8. FISH on mitotic metaphase plates of two Musa interspecific hybrids. (A) Hybrid 'Sar' ITC1213 (2n=3x=32, AAT; Radka5 DNA sequence (red); (B) Hybrid 'Umbubu' ITC0854 ( $2 \mathrm{n}=2 \mathrm{x}=21$, AT; Radka6 DNA sequence (green). Chromosomes were counterstained with DAPI (blue). Bars correspond to $5 \mu \mathrm{m}$.

\section{Conclusions and Future Perspectives}

Current cytogenetic studies on bananas benefit from combining the advantages of two complementary techniques, flow cytometry and fluorescence in situ hybridization (FISH). Flow cytometry is a rapid and reliable method for estimating genome size and ploidy level within the whole Musaceae family. However, this technique cannot be used to determine the chromosome number or detect potential aneuploidy. Methods of molecular cytogenetics based on fluorescence in situ hybridization (FISH) are essential for the unambiguous identification of chromosomes and their number in the genome. Moreover, FISH provides valuable information on genome structural changes that accompany speciation processes.

Traditional probes used for FISH, such as various tandem or dispersed repetitive DNA sequences, rRNA genes, and a few BAC clones, could not identify the individual chromosomes of the three Musaceae genera and did not facilitate comparative karyotype analysis. Oligo painting FISH represents a breakthrough technique in banana molecular cytogenetics. For the first time, all Musa chromosomes were individually identified along with the variation in chromosome structure within different Musa species. This knowledge helped in reconstructing their molecular karyotypes and conducting comparative cytogenetic studies that led to the formation of an independent theory regarding additional evolutionary mechanisms underlying banana speciation. Moreover, information about chromosome structural changes may help banana breeders select appropriate parents during banana breeding processes more efficiently.

Furthermore, chromosome-specific oligo painting was used to analyze more decondensed meiotic pachytene chromosomes and represents a promising tool for the in situ analysis of chromosome pairing during meiosis, especially in interspecific banana hybrid clones consisting of subgenomes varying in unbalanced translocations. As a complementary approach to genomic in situ hybridization (GISH) used to distinguish parental genomes in interspecific banana hybrids, species- or subspecies-specific DNA repeats can be used to unambiguously discriminate parental chromosomes of interspecific hybrids. Apart from their use in the GISH technique which did not ensure successful visualization 
of entire chromosomes, especially in the most important banana hybrid clones originating from crosses between two closely related species (M. acuminata and M. balbisiana), their application in the identification of species-specific repeats as cytogenetic markers can be highly beneficial. Finally, chromosome arm-specific oligo painting probes developed for banana can be used to analyze the three-dimensional organization and positioning of chromosomes during interphase in detail.

Author Contributions: J.Č. performed the flow cytometric and cytogenetic analysis of Musella lasiocarpa; V.Z. performed FISH analysis of A $\times$ T banana hybrid clones; D.Š., J.Č., P.C. and E.H. wrote the manuscript. All authors have read and agreed to the published version of the manuscript.

Funding: This research was funded by the Czech Science Foundation (award no. 19-20303S) and the Ministry of Education, Youth, and Sports of the Czech Republic (Program INTER-EXCELLENCE, INTER-TRANSFER, grant award LTT19009).

Institutional Review Board Statement: Not applicable.

Informed Consent Statement: Not applicable.

Data Availability Statement: Not applicable.

Acknowledgments: We would like to thank the International Transit Centre (ITC, Katholieke Universitiet, Leuven, Belgium) for providing the plant material and Radka Tušková for excellent technical assistance.

Conflicts of Interest: All authors declare no conflict of interest.

\section{References}

1. Häkkinen, M. Reappraisal of sectional taxonomy in Musa (Musaceae). Taxon 2013, 62, 809-813. [CrossRef]

2. Janssens, S.B.; Vandelook, F.; de Langhe, E.; Verstraete, B.; Smets, E.; van den Houwe, I.; Swennen, R. Evolutionary dynamics and biogeography of Musaceae reveal a correlation between the diversification of the banana family and the geological and climatic history of Southeast Asia. New Phytol. 2016, 210, 1453-1465. [CrossRef]

3. FAOSTAT. Agriculture Organization of the United Nations, FAO. 2019. Available online: http://www.fao.org/home/en/ (accessed on 5 June 2021).

4. Cheesman, E.E. Classification of the bananas. The genus Ensete Horan. Kew Bull. 1947, 2, 97-117. [CrossRef]

5. International Plant Genetic Resources Institute-International Network for the Improvement of Banana and Plantain/Centre de Coopération internationale en recherche agronomique pour le développement [IPGRI-INIBAP/CIRAD]. Description for Banana (Musa spp.); Int. Network for the Improvement of Banana and Plantain: Montpellier, France; Centre de coopération int. en recherche agronomique pour le développement: Montpellier, France; International Plant Genetic Resources Institute Press: Rome, Italy, 1996.

6. $\quad$ Argent, G.C.G. The wild bananas of Papua New Guinea. Notes R. Bot. Gard. Edinb. 1976, 35, 77-114.

7. Carreel, F.; Fauré, S.; de León, D.G.; Lagoda, P.J.L.; Perrier, X.; Bakry, F.; Dumontcel, H.T.; Lanaud, C.; Horry, J.P. Evaluation of the genetic diversity in diploid bananas (Musa sp.). Genet. Sel. Evol. 1994, 26, 125-136. [CrossRef]

8. Čížková, J.; Hřibová, E.; Humplíková, L.; Christelová, P.; Suchánková, P.; Doležel, J. Molecular analysis and genomic organization of major DNA satellites in banana (Musa spp.). PLoS ONE 2013, 8, e54808. [CrossRef] [PubMed]

9. Christelová, P.; de Langhe, E.; Hřibová, E.; Čížková, J.; Sardos, J.; Hušáková, M.; van den houwe, I.; Sutanto, A.; Kepler, A.K.; Swennen, R.; et al. Molecular and cytological characterization of the global Musa germplasm collection provides insights into the treasure of banana diversity. Biodivers. Conserv. 2017, 26, 801-824. [CrossRef]

10. Němečková, A.; Christelová, P.; Čížková, J.; Nyine, M.; van den houwe, I.; Svačina, R.; Uwimana, B.; Swennen, R.; Doležel, J.; Hřibová, E. Molecular and cytogenetic study of East African Highland Banana. Front. Plant. Sci. 2018, 9, 1371. [CrossRef]

11. De Langhe, E.; Vrydaghs, L.; de Maret, P.; Perrier, X.; Denham, T.P. Why bananas matter: An introduction to the history of banana domestication. Ethnobot. Res. Appl. 2009, 7, 165-177. [CrossRef]

12. Perrier, X.; de Langhe, E.; Donohue, M.; Lentfer, C.; Vrydaghs, L.; Bakry, F.; Carreel, F.; Hippolyte, I.; Horry, J.P.; Jenny, C.; et al. Multidisciplinary perspectives on banana (Musa spp.) domestication. Proc. Natl. Acad. Sci. USA 2011, 108, 11311-11318. [CrossRef]

13. Simmonds, N.W.; Shepherd, K. The taxonomy and origins of the cultivated bananas. J. Linn. Soc. Bot. 1955, 55, 302-312. [CrossRef]

14. Bennett, M.D.; Johnston, S.; Hodnett, G.L.; Price, H.J. Allium cepa L. cultivars from four continents compared by flow cytometry show nuclear DNA constancy. Ann. Bot. 2000, 85, 351-357. [CrossRef]

15. Loureiro, J.; Trávníček, P.; Rauchová, J.; Urfus, T.; Vit, P.; Štech, M.; Castro, S.; Suda, J. The use of flow cytometry in the biosystematics, ecology and population biology of homoploid plants. Preslia 2010, 82, 3-21. 
16. Doležel, J.; Bartoš, J.; Voglmayr, H.; Greilhuber, J. Nuclear DNA content and genome size of trout and human. Cytometry A. 2003, 51, 127-128. [CrossRef]

17. Doležel, J.; Doleželová, M.; Novák, F.J. Flow cytometric estimation of nuclear DNA amount in diploid bananas (Musa acuminata and M. balbisiana). Biol. Plant. 1994, 36, 351-357. [CrossRef]

18. Lysák, M.A.; Doleželová, M.; Horry, J.P.; Swennen, R.; Doležel, J. Flow cytometric analysis of nuclear DNA content in Musa. Theor. Appl. Genet. 1999, 98, 1344-1350. [CrossRef]

19. D'Hont, A.; Goy, A.P.; Jenny, C.; Noyer, J.L.; Baurens, F.C.; Lagoda, P.; Carreel, F. Investigation of the Complex Genome Structure of Cultivated Banana (Musa spp.) by Flow Cytometry, Genomic DNA In Situ Hybridisation and Repeated Sequence Analysis; Boyce Thompson Institute for Plant Research: New York, NY, USA, 1999.

20. Bartoš, J.; Alkhimova, O.; Doleželová, M.; de Langhe, E.; Doležel, J. Nuclear genome size and genomic distribution of ribosomal DNA in Musa and Ensete (Musaceae): Taxonomic implications. Cytogenet. Genome Res. 2005, 109, 50-57. [CrossRef] [PubMed]

21. Čížková, J.; Hřibová, E.; Christelová, P.; van den Houwe, I.; Häkkinen, M.; Roux, N.; Swennen, R.; Doležel, J. Molecular and cytogenetic characterization of wild Musa species. PLoS ONE 2015, 10, e0134096. [CrossRef] [PubMed]

22. Roux, N.; Toloza, A.; Radecki, Z.; Zapata-Arias, F.J.; Doležel, J. Rapid detection of aneuploidy in Musa using flow cytometry. Plant Cell Rep. 2003, 21, 483-490. [CrossRef] [PubMed]

23. MacDaniels, L.H. A Study of the Fe'i Banana and its Distribution With Reference to Polynesian Migrations; Bernice P. Bishop Museum: Honolulu, HI, USA, 1947; pp. 1-56.

24. Gouy, M.; Guindon, S.; Gascuel, O. SeaView version 4: A multiplatform graphical user interface for sequence alignment and phylogenetic tree building. Mol. Biol. Evol. 2010, 27, 221-224. [CrossRef] [PubMed]

25. Doleželová, M.; Valárik, M.; Swennen, R.; Horry, J.P.; Doležel, J. Physical mapping of the 18S-25S and 5S ribosomal RNA genes in diploid bananas. Biol. Plant. 1998, 41, 497-505. [CrossRef]

26. Osuji, J.O.; Crouch, J.; Harrison, G.; Heslop-Harrison, J.S. Molecular cytogenetics of Musa species, cultivars and hybrids: Location of 18S-5.8S-25S and 5S rDNA and telomere-like sequences. Ann. Bot. 1998, 82, 243-248. [CrossRef]

27. Valárik, M.; Šimková, H.; Hřibová, E.; Šafář, J.; Doleželová, M.; Doležel, J. Isolation, characterization and chromosome localization of repetitive DNA sequences in bananas (Musa spp.). Chromosome Res. 2002, 10, 89-100. [CrossRef] [PubMed]

28. Sandoval, J.A.; Côte, F.X.; Escoute, J. Chromosome number variations in micropropagated true-to-type and off-type banana plants (Musa AAA Grande Naine cv.). In Vitro Cell. Dev. Biol. Plant. 1996, 32, 14-17. [CrossRef]

29. Shepherd, K.; da Silva, K.M. Mitotic instability in banana varieties. Aberrations in conventional triploid plants. Fruits 1996, 51, 99-103.

30. Pardue, M.L.; Gall, J.G. Chromosomal localization of mouse satellite DNA. Science 1970, 168, 1356-1358. [CrossRef]

31. Arrighi, F.E.; Hsu, T.C. Localization of heterochromatin in human chromosomes. Cytogenet. Genome Res. 1971, 10, 81-86. [CrossRef]

32. Comings, D.E. Mechanisms of chromosome banding and implications for chromosome structure. Ann. Rev. Genet. 1978, 12, 25-46. [CrossRef] [PubMed]

33. Gill, B.S.; Friebe, B.; Endo, T.R. Standard karyotype and nomenclature system for description of chromosome bands and structural aberrations in wheat (Triticum aestivum). Genome 1991, 34, 830-839. [CrossRef]

34. Gill, B.S.; Kimber, G. Recognition of translocations and alien chromosome transfers in wheat by the giemsa C-banding technique. Crop. Sci. 1977, 17, 264-266. [CrossRef]

35. Song, Y.C.; Liu, L.H.; Ding, Y.; Tian, X.B.; Yao, Q.; Meng, L.; He, C.R.; Xu, M.S. Comparisons of G-banding patterns in six species of the Poaceae. Hereditas 1994, 121, 31-38. [CrossRef]

36. Lim, K.B.; Wennekes, J.; de Jong, H.; Jacobsen, E.; Tuyl, J.M. Karyotype analysis of Lilium longiflorum and Lilium rubellum by chromosome banding and fluorescence in situ hybridisation. Genome 2001, 44, 911-918. [CrossRef] [PubMed]

37. Langer-Safer, P.R.; Levine, M.; Ward, D.C. Immunological method for mapping genes on Drosophila polytene chromosomes. Proc. Natl. Acad. Sci. USA 1982, 79, 4381-4385. [CrossRef] [PubMed]

38. Jiang, J.M.; Gill, B.S. Current status and the future of fluorescence in situ hybridization (FISH) in plant genome research. Genome 2006, 49, 1057-1068. [CrossRef] [PubMed]

39. Koo, D.H.; Zhao, H.; Jiang, J. Chromatin-associated transcripts of tandemly repetitive DNA sequences revealed by RNA-FISH Chromosome Res. 2016, 24, 467-480. [CrossRef] [PubMed]

40. Křivánková, A.; Kopecký, D.; Stočes, Š.; Doležel, J.; Hřibová, E. Repetitive DNA: A versatile tool for karyotyping in Festuca pratensis Huds. Cytogenet. Genome Res. 2017, 151, 96-105. [CrossRef] [PubMed]

41. Ruban, A.; Badaeva, E.D. Evolution of the S-genomes in Triticum-Aegilops alliance: Evidences from chromosome analysis. Front. Plant Sci. 2018, 9, 1756. [CrossRef] [PubMed]

42. Deng, H.; Tang, G.; Xu, N.; Gao, Z.; Lin, L.; Liang, D.; Xia, H.; Deng, Q.; Wang, J.; Cai, Z.; et al. Integrated karyotypes of diploid and tetraploid Carrizo Citrange (Citrus sinensis L. Osbeck $\times$ Poncirus trifoliata L. Raf.) as determined by dequential multicolor fluorescence in situ hybridization with tandemly repeated DNA sequences. Front. Plant Sci. 2020, 11, 569. [CrossRef] [PubMed]

43. Lysák, M.A.; Fransz, P.F.; Ali, H.B.M.; Schubert, I. Chromosome painting in A. thaliana. Plant J. 2001, 28, 689-697. [CrossRef]

44. Bielski, W.; Książkiwicz, M.; Šimoníková, D.; Hřibová, E.; Susek, K.; Naganowska, B. The puzzling fate of a lupin chromosome revealed by reciprocal oligo-FISH and BAC FISH mapping. Genes 2020, 11, e1489. [CrossRef] 
45. Jiang, J.; Gill, B.S. Different species-specific chromosome translocations in Triticum timopheevii and T. turgidum support the diphyletic origin of polyploid wheats. Chromosom. Res. 1994, 2, 59-64. [CrossRef] [PubMed]

46. Hřibová, E.; Doleželová, M.; Doležel, J. Localization of BAC clones on mitotic chromosomes of Musa acuminata using fluorescence in situ hybridization. Biol. Plant. 2008, 52, 445-452. [CrossRef]

47. Zwyrtková, J.; Němečková, A.; Č́žzová, J.; Holušová, K.; Kapustová, V.; Svačina, R.; Kopecký, D.; Till, B.J.; Doležel, J.; Hřibová, E. Comparative analyses of DNA repeats and identification of a novel Fesreba centromeric element in fescues and ryegrasses. $B M C$ Plant Biol. 2020, 20, 280. [CrossRef] [PubMed]

48. Danilova, T.V.; Friebe, B.; Gill, B.S. Single-copy gene Fluorescence in situ hybridization and genome analysis: Acc-2 loci mark evolutionary chromosomal rearrangements in wheat. Chromosoma 2012, 121, 597-611. [CrossRef] [PubMed]

49. Karafiátová, M.; Bartoš, J.; Doležel, J. Localization of Low-Copy DNA Sequences on Mitotic Chromosomes by FISH. In Plant Cytogenetics. Methods in Molecular Biology; Kianian, S., Kianian, P., Eds.; Humana Press: New York, NY, USA, 2016; Volume 1429, pp. 49-64. [CrossRef]

50. Said, M.; Hřibová, E.; Danilova, T.V.; Karafiátová, M.; Čížková, J.; Friebe, B.; Doležel, J.; Gill, B.S.; Vrána, J. The Agropyron cristatum karyotype, chromosome structure and crossgenome homoeology as revealed by fluorescence in situ hybridization with tandem repeats and wheat single-gene probes. Theor. Appl. Genet. 2018, 131, 2213-2227. [CrossRef] [PubMed]

51. Badaeva, E.D.; Friebe, B.; Gill, B.S. Genome differentiation in Aegilops. 2. Physical mapping of 5S and 18S-26S ribosomal RNA gene families in diploid species. Genome 1996, 39, 1150-1158. [CrossRef] [PubMed]

52. Hasterok, R.; Jenkins, G.; Langdon, T.; Jones, R.N.; Maluszynska, J. Ribosomal DNA is an effective marker of Brassica chromosomes. Theor. Appl. Genet. 2001, 103, 486-490. [CrossRef]

53. Liu, B.; Davis, T.M. Conservation and loss of ribosomal RNA gene sites in diploid and polyploid Fragaria (Rosaceae). BMC Plant Biol. 2011, 11, 157. [CrossRef]

54. Šimoníková, D.; Němečková, A.; Karafiátová, M.; Uwimana, B.; Swennen, R.; Doležel, J.; Hřibová, E. Chromosome painting facilitates anchoring reference genome sequence to chromosomes in situ and integrated karyotyping in banana (Musa spp.). Front. Plant Sci. 2019, 10, 1503. [CrossRef]

55. Pedersen, C.; Langridge, P. Identification of the entire chromosome complement of bread wheat by two-colour FISH. Genome 1997, 40, 589-593. [CrossRef] [PubMed]

56. Badaeva, E.D.; Amosova, A.V.; Goncharov, N.P.; Macas, J.; Ruban, A.S.; Grechishnikova, I.V.; Zoshchuk, S.A.; Houben, A. A Set of Cytogenetic Markers Allows the Precise Identification of All A-Genome Chromosomes in Diploid and Polyploid Wheat. Cytogenet. Genome Res. 2015, 146, 71-79. [CrossRef] [PubMed]

57. Liu, W.; Rouse, M.; Friebe, B.; Jin, Y.; Gill, B.; Pumphrey, M.O. Discovery and molecular mapping of a new gene conferring resistance to stem rust, Sr53, derived from Aegilops geniculata and characterization of spontaneous translocation stocks with reduced alien chromatin. Chromosom. Res. 2011, 19, 669-682. [CrossRef] [PubMed]

58. Balint-Kurti, P.; Clendennen, S.; Doleželová, M.; Valárik, M.; Doležel, J.; Beetham, P.R.; May, G.D. Identification and chromosomal localization of the monkey retrotransposon in Musa sp. Mol. Gen. Genet. 2000, 263, 908-915. [CrossRef] [PubMed]

59. Hřibová, E.; Doleželová, M.; Town, C.D.; Macas, J.; Doležel, J. Isolation and characterization of the highly repeated fraction of the banana genome. Cytogenet. Genome Res. 2007, 119, 268-274. [CrossRef] [PubMed]

60. Hřibová, E.; Neumann, P.; Matsumoto, T.; Roux, N.; Macas, J.; Doležel, J. Repetitive part of the banana (Musa acuminata) genome investigated by lowdepth 454 sequencing. BMC Plant Biol. 2010, 10, 204. [CrossRef]

61. Novák, P.; Hřibová, E.; Neumann, P.; Koblížková, A.; Doležel, J.; Macas, J. Genome-wide analysis of repeat diversity across the family Musaceae. PLoS ONE 2014, 9, e98918. [CrossRef] [PubMed]

62. Neumann, P.; Navrátilová, A.; Koblížková, A.; Kejnovský, E.; Hřibová, E.; Hobza, R.; Widmer, A.; Doležel, J.; Macas, J. Plant centromeric retrotransposoms: A structural and cytogenetic perspective. Mob. DNA 2011, 2, 4. [CrossRef]

63. Jiang, J.M.; Gill, B.S.; Wang, G.L.; Ronald, P.C.; Ward, D.C. Metaphase and interphase fluorescence in-situ hybridization mapping of the rice genome with bacterial artificial chromosomes. Proc. Nat. Acad. Sci. USA 1995, 92, 4487-4491. [CrossRef]

64. Lapitan, N.L.V.; Brown, S.E.; Kennard, W.; Stephens, J.L.; Knudson, D.L. FISH physical mapping with barley BAC clones. Plant J. 1997, 11, 149-156. [CrossRef]

65. Kim, J.S.; Childs, K.L.; Islam-Faridi, M.N.; Menz, M.A.; Klein, R.R.; Klein, P.E.; Price, H.J.; Mullet, J.E.; Stelly, D.M. Integrated karyotyping of sorghum by in situ hybridization of landed BACs. Genome 2002, 45, 402-412. [CrossRef]

66. Idziak, D.; Hazuka, I.; Poliwczak, B.; Wiszynska, A.; Wolny, E.; Hasterok, R. Insight into the karyotype evolution of Brachypodium species using comparative chromosome barcoding. PLoS ONE 2014, 9, e93503. [CrossRef] [PubMed]

67. Vilarinhos, A.; Carreel, F.; Rodier, M.; Hippolyte, I.; Benabdelmouna, A.; Triaire, D.; Bakry, F. Characterization of translocations in banana by FISH of BAC clones anchored to a genetic map. In Abstracts of Plant and Animal Genomes XIVth Conference; Sherago International: San Diego, CA, USA, 2006.

68. De Capdeville, G.; Souza, M.T., Jr.; Szinay, D.; Diniz, L.E.C.; Wijnker, E.; Swennen, R.; Kema, G.H.J.; de Jong, H. The potential of high-resolution BAC-FISH in banana breeding. Euphytica 2009, 166, 431-443. [CrossRef]

69. D’Hont, A.; Denoeud, F.; Aury, J.M.; Baurens, F.C.; Carreel, F.; Garsmeur, O.; Noel, B.; Bocs, S.; Droc, G.; Rouard, M.; et al. The banana (Musa acuminata) genome and the evolution of monocotyledonous plants. Nature 2012, 488, 213-217. [CrossRef] [PubMed] 
70. Martin, G.; Carreel, F.; Coriton, O.; Hervouet, C.; Cardi, C.; Derouault, P.; Roques, D.; Salmon, F.; Rouard, M.; Sardos, J.; et al. Evolution of the banana genome (Musa acuminata) is impacted by large chromosomal translocations. Mol. Biol. Evol. 2017, 34, 2140-2152. [CrossRef] [PubMed]

71. Martin, G.; Baurens, F.C.; Hervouet, C.; Salmon, F.; Delos, J.M.; Labadie, K.; Perdereau, A.; Mournet, P.; Blois, L.; Dupouy, M.; et al. Chromosome reciprocal translocations have accompanied subspecies evolution in bananas. Plant J. 2020, 104, $1698-1711$. [CrossRef]

72. Jiang, J. Fluorescence in situ hybridization in plants: Recent developments and future applications. Chromosom. Res. 2019, 27, 153-165. [CrossRef]

73. Qu, M.; Li, K.; Han, Y.; Chen, L.; Li, Z.; Han, Y. Integrated karyotyping of woodland strawberry (Fragaria vesca) with oligopaint FISH probes. Cytogenet. Genome Res. 2017, 153, 158-164. [CrossRef] [PubMed]

74. Bačovský, V.; Čegan, R.; Šimoníková, D.; Hřibová, E.; Hobza, R. The formation of sex chromosomes in Silene latifolia and S. dioica was accompanied by multiple chromosomal rearrangements. Front. Plant Sci. 2020, 11, 205. [CrossRef]

75. Han, Y.; Zhang, T.; Thammapichai, P.; Weng, Y.; Jiang, J. Chromosome-specific painting in Cucumis species using bulked oligonucleotides. Genetics 2015, 200, 771-779. [CrossRef]

76. Liu, G.; Zhang, T. Single copy oligonucleotide fluorescence in situ hybridization probe design platforms: Development, application and evolution. Int. J. Mol. Sci. 2021, 22, 7124. [CrossRef]

77. Hou, L.; Xu, M.; Zhang, T.; Xu, Z.; Wang, W.; Zhang, J.; Yu, M.; Ji, W.; Zhu, C.; Gong, Z.; et al. Chromosome painting and its applications in cultivated and wild rice. BMC Plant Biol. 2018, 18, 110. [CrossRef] [PubMed]

78. Meng, Z.; Zhang, Z.L.; Yan, T.Y.; Lin, Q.F.; Wang, Y.; Huang, W.; Huang, Y.; Li, Z.; Yu, Q.; Wang, J.; et al. Comprehensively characterizing the cytological features of Saccharum spontaneum by the development of a complete set of chromosome-specific oligo probes. Front. Plant. Sci. 2018, 9, 1624. [CrossRef] [PubMed]

79. Meng, Z.; Han, J.; Lin, Y.; Zhao, Y.; Lin, Q.; Ma, X.; Wang, J.; Zhang, M.; Zhang, L.; Yang, Q.; et al. Characterization of a Saccharum spontaneum with a basic chromosome number of $\mathrm{x}=10$ provides new insights on genome evolution in genus Saccharum. Theoret. Appl. Genet. 2020, 133, 187-199. [CrossRef]

80. Albert, P.S.; Zhang, T.; Semrau, K.; Rouillard, J.M.; Kao, Y.H.; Wang, C.R.; Danilova, T.V.; Jiang, J.; Birchler, J.A. Wholechromosome paints in maize reveal rearrangements, nuclear domains, and chromosomal relationships. Proc. Natl. Acad. Sci. USA 2019, 116, 1679-1685. [CrossRef] [PubMed]

81. Do Vale Martins, L.; Yu, F.; Zhao, H.; Dennison, T.; Lauter, N.; Wang, H.; Deng, Z.; Thompson, A.; Semrau, K.; Rouilard, J.M.; et al Meiotic crossovers characterized by haplotype-specific chromosome painting in maize. Nat. Commun. 2019, 10, 4604. [CrossRef]

82. Liu, X.; Sun, S.; Wu, Y.; Zhou, Y.; Gu, S.; Yu, H.; Yi, C.; Gu, M.; Jiang, J.; Liu, B.; et al. Dual-color oligo-FISH can reveal chromosomal variations and evolution in Oryza species. Plant J. 2020, 101, 112-121. [CrossRef]

83. Braz, G.T.; Martins, L.D.; Zhang, T.; Albert, P.S.; Birchler, J.A.; Jiang, J. A universal chromosome identification system for maize and wild Zea species. Chromosome Res. 2020, 28, 183-194. [CrossRef]

84. Song, X.; Song, R.; Zhou, J.; Yan, W.; Zhang, T.; Sun, H.; Xiao, J.; Wu, Y.; Xi, M.; Lou, Q.; et al. Development and application of oligonucleotide-based chromosome painting for chromosome 4D of Triticum aestivum L. Chromosome Res. 2020, 28, 171-182. [CrossRef]

85. Braz, G.T.; He, L.; Zhao, H.; Zhang, T.; Semrau, K.; Rouillard, J.M.; Torres, G.A.; Jiang, J. Comparative oligo-FISH mapping: An efficient and powerful methodology to reveal karyotypic and chromosomal evolution. Genetics 2018, 208, 513-523. [CrossRef]

86. He, L.; Braz, G.T.; Torres, G.A.; Jiang, J.M. Chromosome painting in meiosis reveals pairing of specific chromosomes in polyploid Solanum species. Chromosoma 2018, 127, 505-513. [CrossRef]

87. Do Vale Martins, L.; de Oliveira Bustamante, F.; da Silva Oliveira, A.R.; da Costa, A.F.; de Lima Feitoza, L.; Liang, Q.; Zhao, H.; Benko-Iseppon, A.M.; Munoz-Amatriaín, M.; Pedrosa-Harand, A.; et al. BAC- and oligo-FISH mapping reveals chromosome evolution among Vigna angularis, V. unguiculata, and Phaseolus vulgaris. Chromosoma 2021, 130, 133-147. [CrossRef] [PubMed]

88. Martin, G.; Baurens, F.C.; Droc, G.; Rouard, M.; Cenci, A.; Kilian, A.; Hastie, A.; Doležel, J.; Aury, J.B.; Alberti, A.; et al. Improvement of the banana "Musa acuminata" reference sequence using NGS data and semi-automated bioinformatics methods. BMC Genomics 2016, 17, 243. [CrossRef] [PubMed]

89. Šimoníková, D.; Němečková, A.; Čížková, J.; Brown, A.; Swennen, R.; Doležel, J.; Hřibová, E. Chromosome painting in cultivated bananas and their wild relatives (Musa spp.) reveals differences in chromosome structure. Int. J. Mol. Sci. 2020, $21,7915$. [CrossRef] [PubMed]

90. Schwarzacher, T.; Leitch, A.R.; Bennett, M.D.; Heslop-Harrison, J.S. In situ localization of parental genomes in a wide hybrid. Ann. Bot. 1989, 64, 315-324. [CrossRef]

91. Haider Ali, S.; Ramanna, M.; Jacobsen, E.; Visser, R.G.F. Genome differentiation between Lycopersicon esculentum and L. pennellii as revealed by genomic in situ hybridization. Euphytica 2002, 127, 227-234. [CrossRef]

92. Snowdon, R.J. Cytogenetics and genome analysis in Brassica crops. Chromosome Res. 2007, 15, 85-95. [CrossRef]

93. Benavente, E.; Cifuentes, M.; Dusautoir, J.C.; David, J. The use of cytogenetic tools for studies in the crop-to-wild gene transfer scenario. Cytogenet. Genome Res. 2008, 120, 384-395. [CrossRef]

94. Silva, G.S.; Souza, M.M. Genomic in situ hybridization in plants. Genet. Mol. Res. 2013, 12, 2953-2965. [CrossRef]

95. Kopecký, D.; Šimoníková, D.; Ghesquière, M.; Doležel, J. Stability of genome composition and recombination between homoeologous chromosomes in Festulolium $($ Festuca $\times$ Lolium) cultivars. Cytogenet. Genome Res. 2017, 151, 106-114. [CrossRef] 
96. Parokonny, A.S.; Marshall, J.A.; Bennett, M.D.; Cocking, E.C.; Davey, M.R.; Power, J.B. Homoeologous pairing and recombination in backcross derivatives of tomato somatic hybrids [Lycopersicon esculentum (+) L. peruvianum]. Theor. Appl. Genet. 1997, 94, 713-723. [CrossRef]

97. D'Hont, A.; Paget-Goy, A.; Escoute, J.; Carreel, F. The interspecific genome structure of cultivated banana, Musa spp. revealed by genomic DNA in situ hybridization. Theor. Appl. Genet. 2000, 100, 177-183. [CrossRef]

98. Osuji, J.O.; Harrisson, G.; Crouch, J.; Heslop-Harrison, J.S. Identification of the genomic constitution of Musa L. lines (Bananas, Plantains and hybrids) using molecular cytogenetics. Ann. Bot. 1997, 80, 787-793. [CrossRef]

99. Jeridi, M.; Bakry, F.; Escoute, J.; Fondi, E.; Carreel, F.; Ferchichi, A.; D’Hont, A.; Rodier-Goud, M. Homoeologous chromosome pairing between the A and B genomes of Musa spp. revealed by genomic in situ hybridization. Ann. Bot. 2011, 108, 975-981. [CrossRef] [PubMed] 